University of Nebraska - Lincoln

DigitalCommons@University of Nebraska - Lincoln

Nebraska Beef Cattle Reports

Animal Science Department

2020

\title{
Impact of Essential Oils Blend on Beef Cattle Performance and Carcass Characteristics in Diets with Increasing Corn Silage Inclusions
}

\author{
Hannah C. Wilson \\ University of Nebraska - Lincoln \\ Bradley M. Boyd \\ University of Nebraska - Lincoln \\ F. Henry Hilscher \\ University of Nebraska - Lincoln \\ Zachary E. Carlson \\ University of Nebraska - Lincoln \\ Andrea K. Watson \\ University of Nebraska at Lincoln, awatson3@unl.edu
}

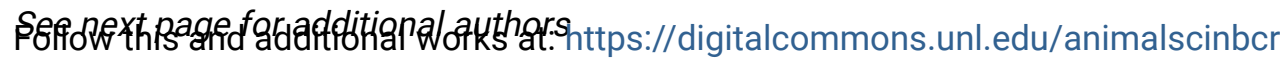

Part of the Large or Food Animal and Equine Medicine Commons, Meat Science Commons, and the Veterinary Preventive Medicine, Epidemiology, and Public Health Commons

Wilson, Hannah C.; Boyd, Bradley M.; Hilscher, F. Henry; Carlson, Zachary E.; Watson, Andrea K.; MacDonald, J. C.; and Erickson, Galen E., "Impact of Essential Oils Blend on Beef Cattle Performance and Carcass Characteristics in Diets with Increasing Corn Silage Inclusions" (2020). Nebraska Beef Cattle Reports. 1076.

https://digitalcommons.unl.edu/animalscinbcr/1076

This Article is brought to you for free and open access by the Animal Science Department at DigitalCommons@University of Nebraska - Lincoln. It has been accepted for inclusion in Nebraska Beef Cattle Reports by an authorized administrator of DigitalCommons@University of Nebraska - Lincoln. 


\section{Authors}

Hannah C. Wilson, Bradley M. Boyd, F. Henry Hilscher, Zachary E. Carlson, Andrea K. Watson, J. C. MacDonald, and Galen E. Erickson 


\section{Impact of Essential Oils Blend on Beef Cattle Performance and Carcass Characteristics in Diets with Increasing Corn Silage Inclusions}

\author{
Hannah C. Wilson \\ F. Henry Hilscher \\ Bradley M. Boyd \\ Andrea K. Watson \\ Jim C. MacDonald \\ Galen E. Erickson
}

\section{Summary with Implications}

A feedlot study was conducted comparing a natural feed additive (essential oils blend) at varying corn silage (CS) inclusions (14, 47, and $80 \%$; DM basis) on receiving and finishing performance. Essential oils have been shown to alter the rumen environment leading to improved feed efficiency and production. Cattle were fed 14\% CS for 168 days, 47\% CS for 195 days, and 80\% CS for 238 days to a common backfat of 0.5 inches. There were no interactions between the inclusion of the essential oil blend and corn silage for performance or carcass characteristics. There was no significant difference in performance or carcass characteristics for cattle fed with or without essential oils. Feeding corn silage at greater inclusions decreased gain and increased conversion but increased final body weight when fed to an equal fatness. Additionally, greater inclusions of silage led to increased profitability in dollars per head sold. Essential oils did not affect animal performance or carcass characteristics. However, feeding greater amounts of corn silage can be economical.

\section{Introduction}

Increasing restriction on medically important antibiotics in food animal production have led to interest in antibiotic alternatives. Feeding essential oils may help prevent ruminal acidosis, bloat, digestive and metabolic upsets. Essential oils (EO), derived from plant extracts, have been shown to alter ruminal metabolism to improve feed efficiency by manipulating microbial activity in the rumen. In most

(C) The Board Regents of the University of Nebraska. All rights reserved. studies researchers have found a decrease, or no change, in total VFA concentration but observed a shift to more propionate. However, effects of plant extracts on ruminal microbial fermentation are $\mathrm{pH}$ dependent. This would be important when evaluating essential oil supplementation in various inclusions of concentrate. Few studies have been performed to evaluate the effects of EO on beef cattle performance. As corn silage is added to a diet replacing corn grain, energy density decreases, and less energy is available for gain. This is a valuable tool to mimic different stages of production to assess the impacts of feed additives at different concentrate levels. The objective of this study was to determine the impact of an essential oils mixture (palm oil and fumaric acid) on the performance and carcass characteristics of beef cattle fed different inclusions of corn silage.

\section{Procedure}

A finishing experiment conducted at the Eastern Nebraska Research and Extension Center utilized 480 crossbred steers (initial shrunk BW $652 \mathrm{lbs} \pm 53.0 \mathrm{lbs}$ ). Cattle were limit fed a diet at $2 \%$ of BW for $5 \mathrm{~d}$ prior to the start of the experiment. Two-day initial weights were recorded on $\mathrm{d} 0$ and 1 which were averaged and used as the initial BW. The steers were blocked by BW into three weight blocks, light, middle, and heavy, (n $=12,24$, and 12 pen replicates, respectively) based on $\mathrm{d} 0 \mathrm{BW}$, stratified by BW within block and assigned randomly to 1 of 48 pens. There were 10 steers/pen and 8 replications per treatment. Treatment design was a $2 \times 3$ factorial with 3 inclusions of corn silage $(14,47,80)$ with or without $(+$, -) the inclusion of an essential oils blend (14 CS +EO, 14 CS -EO, 47 CS +EO, 47 CS -EO, 80 CS +EO, 80 CS -EO; Table 1).

Steers were fed at $80 \% \mathrm{CS}$ inclusion and adapted to $47 \%$ and $14 \%$ CS over a 10 and 24-d period, respectively, with dry-rolled corn replacing alfalfa hay and corn silage. Diets were formulated to meet or exceed NRC requirements for protein and minerals. The final finishing diets provided $330 \mathrm{mg} /$ steer daily of Rumensin (30 g/ton of DM; Elanco Animal Health), and $90 \mathrm{mg} / \mathrm{steer}$ daily of Tylan $(8.2 \mathrm{~g} / \mathrm{ton}$ of DM; Elanco Animal Health). The +EO supplements were formulated to supply $0.2 \%$ of the diet DM as EO (Idena SAS, Sautron, France). The EO blend contained palm oil, fumaric acid, and artificial flavors in a calcium carbonate and sodium sulfate carrier. Steers were implanted on day 1 with Revalor-XS (Merck Animal Health) and received a Bovi-Shield Gold One Shot, Dectomax injection, and Somubac (Zoetis Animal Health). Feed samples were taken weekly, composited on a monthly basis, and analyzed for organic matter $(\mathrm{OM})$, neutral detergent fiber (NDF), acid detergent fiber (ADF), and crude protein (CP).

Cattle fed $80 \%$ CS were fed for 238 days, $47 \%$ CS for 195 days, and 14\% CS were fed for 168 days. Days on feed were determined by estimating finishing backfat using ultrasound. Steers were shipped to Greater Omaha for harvest, and carcass data were recorded. On day of harvest, hot carcass weight was collected. Following a 48-hour chill, USDA marbling score, longissimus muscle (LM) area, and $12^{\text {th }}$ rib fat thickness were recorded. Carcass-adjusted performance was calculated using final body weight (BW), based on hot carcass weight (HCW) divided by a common dressing percentage of 63 .

\section{Corn silage economics}

Corn silage inclusion was economically evaluated using corn price based on market prices for September (\$3.67). Dry corn price was calculated using $\$ 3.67$ plus an average $\$ 0.20$ ( $+\$ 0.05$ per month on feed) with $\$ 2.17 /$ ton DM charged for processing costs. Using the $\$ 3.67$ corn price, a corn silage pricing application from Iowa State University (Silage Pricer-Corn Silage. Version 1.4_82017. Iowa State Extension) was used to price corn silage at $\$ 43.99$ per ton as-is ( $\$ 110 /$ ton DM, 37\% DM), which accounted for $15 \%$ DM basis silage shrink 
Table 1. Composition (\% of diet DM) of dietary treatments fed to steers on varying inclusions of corn silage.

\begin{tabular}{|c|c|c|c|c|c|c|}
\hline \multirow[b]{3}{*}{ Ingredient } & \multicolumn{6}{|c|}{ Treatment $^{1}$} \\
\hline & \multicolumn{3}{|c|}{$-\mathrm{EO}$} & \multicolumn{3}{|c|}{$+\mathrm{EO}$} \\
\hline & $14 \mathrm{CS}$ & $47 \mathrm{CS}$ & $80 \mathrm{CS}$ & $14 \mathrm{CS}$ & $47 \mathrm{CS}$ & $80 \mathrm{CS}$ \\
\hline Dry-rolled corn & 66 & 33 & - & 66 & 33 & - \\
\hline Modified DGS & 16 & 16 & 16 & 16 & 16 & 16 \\
\hline Limestone & 1.65 & 1.65 & 1.65 & 1.65 & 1.65 & 1.65 \\
\hline Urea & 0.6 & 0.6 & 0.6 & 0.6 & 0.6 & 0.6 \\
\hline Salt & 0.3 & 0.3 & 0.3 & 0.3 & 0.3 & 0.3 \\
\hline Essential Oils Blend ${ }^{3}$ & - & - & - & 0.2 & 0.2 & 0.2 \\
\hline Vitamin A-D-E Premix & 0.015 & 0.015 & 0.015 & 0.015 & 0.015 & 0.015 \\
\hline Tylosin ${ }^{5}$ Premix & 0.011 & 0.011 & 0.011 & - & - & - \\
\hline \multicolumn{7}{|l|}{ Nutrient Composition, \% DM } \\
\hline Organic Matter & 96.2 & 94.9 & 93.7 & 96.0 & 94.7 & 93.5 \\
\hline Neutral Detergent Fiber & 21.9 & 32.1 & 42.2 & 22.0 & 32.2 & 42.4 \\
\hline Crude Protein & 15.5 & 15.2 & 15.0 & 15.5 & 15.3 & 15.0 \\
\hline Ether Extract & 4.1 & 3.9 & 3.7 & 4.1 & 3.9 & 3.7 \\
\hline \multicolumn{7}{|l|}{${ }^{1} \mathrm{CS}=$ corn silage; $\mathrm{EO}=$ essential oils. } \\
\hline \multicolumn{7}{|c|}{${ }^{2}$ Supplement fed at $4 \%$ of dietary DM for all treatments. } \\
\hline \multicolumn{7}{|c|}{${ }^{3}$ Formulated to supply AL630US (Idena SAS; France) at $0.2 \%$ of the diet DM; EO contains palm oil, fumaric acid, and artificial flavors } \\
\hline
\end{tabular}

and manure value. Manure credit was assessed as spreading 1 in 4 -year rotation to replace phosphorus with the subtraction of hauling expenses and opportunity cost of corn grain and stover removal. The value of manure was calculated using The Beef Feed Nutrient Management Planning Economics (BFNMP\$) software using 45\% silage-based diet with $20 \%$ WDGS. Cattle interest charges were set at $7.5 \%$ over the feeding period (days on feed/365) including a $\$ 200$ deposit. The cost of MDGS was set at $90 \%$ the price of corn (DM basis) including 5\% shrink. Supplement, including monensin and tylosin, was $\$ 300$ / ton (DM basis) with $1 \%$ shrink applied. Feed interest of $7.5 \%$ was applied to half of the total feed amount to average total usage throughout the feeding period. Medicinal and processing charges were $\$ 20 /$ head and yardage was charged to $\$ 0.50 / \mathrm{hd} /$ day. Initial cattle purchase price $(\$ 1.8382$ / cwt) was calculated to target a net return of $\$ 0$ / head for cattle on the $14 \%$ silage treatment.
Returns were calculated as the difference in gross inputs and revenues where values represented profit in dollars per head ( $\$$ / hd). Returns were calculated using final body weights with a $63 \%$ common dressing percent to calculate live final weight and 5 -year average live fat price for Nebraska (\$1.3055 / cwt).

Data from the last five years had a correlation $\left(r^{2}=0.56\right)$ between feeder price and fat cattle (Livestock Marketing Information Center; lmic.info). Lower correlation was observed in the last 5 years between feeder price and corn price $\left(r^{2}=0.35\right)$. However, historically, corn price and feeder calf price have been inversely related. A sensitivity analysis was conducted to assess the changes in returns based on changing corn price and feeder calf price. Corn silage prices floated with the price of corn using the September market price. Corn silage price compared to $\$ 3.00, \$ 4.00$, and $\$ 5.00$ corn was $\$ 37.18$ (per ton DM), $\$ 45.00, \$ 52.82$, respectively. Feeder calf price was set to break even at $14 \%$ corn silage inclusion.

\section{Statistical Analysis}

Carcass and performance data were analyzed using the MIXED procedure of SAS (SAS Institute, Inc. Cary, N.C.) where pen was the experimental unit. PROC GLIMMIX of SAS using a multinomial distribution to evaluate distribution differences due to treatment, with block as random to account for overdispersion. Two pens were removed from the analysis after a gate failure allowing cattle to be mixed for an unknown period of time (one rep from 47 -EO and $80+\mathrm{EO}$ ). Treatment differences were declared significant for all statistical analysis at $P \leq 0.05$.

\section{Results}

All cattle were fed to a common back fat of 0.51 inches $(P=0.98)$ to ensure equal de- 
gree of finish when comparing performance and carcass characteristics. There was no significant interaction $(P \geq 0.60)$ between the inclusion of EO in the diet and the inclusion level of silage for all of the carcass adjusted animal performance. There were also no differences interactions observed for carcass characteristics $(P \geq 0.15)$.

\section{Essential Oils Effects}

There was no significant difference $(P$ $>0.49$ ) for the inclusion of essential oils for carcass adjusted animal performance including final body weight, DMI, ADG, and F:G (Table 2). Similarly, there were no differences in HCW or calculated yield grade $(\mathrm{P} \leq 0.72)$. There was a tendency $(P$ $=0.13)$ for marbling to be slightly greater and for LM area to be greater $(P=0.04)$ for cattle fed no essential oils. However, these differences were small and were not significant enough to yield additional profit.

\section{Corn Silage Effects}

There was a significant difference in final body weight and HCW with increasing silage inclusion to have a quadratic effect on body weight $(P<0.01$; Table 3$)$. Cattle fed $80 \%$ corn silage had the greatest final body weight, followed by $47 \%$ corn silage, and least for $14 \%$ corn silage. There was a quadratic response for ADG and F:G $(P=0.04)$. Cattle fed 14 CS had the greatest ADG followed by $47 \mathrm{CS}$, and least for 80 CS which had poorer ADG as days on feed increased. Dry matter intake was not significantly different for the 3 silage inclusions $(P=0.96)$. There was a quadratic response $(P<0.01)$ for $\mathrm{F}$ :G with cattle fed $14 \mathrm{CS}$ having the lowest F: $\mathrm{G}$, followed by 47 CS, and highest for $80 \mathrm{CS}$.

There was a linear response for LM area where cattle fed $14 \mathrm{CS}$ had the greatest LM area, 47 CS was intermediate, and least for $80 \%$ CS. Marbling score was quadratic with cattle fed 14 CS having the greatest mar-

bling score, 80 CS was intermediate, and 47 CS was least.

\section{Corn Silage Economics}

An analysis on the profitability of feeding increasing amounts of corn silage and the economic sensitivity of profitability due to changes in feed costs and finished
Table 2. Main effect of essential oils on carcass adjusted performance on cattle fed three inclusions of corn silage with or without essential oils.

\begin{tabular}{|c|c|c|c|c|}
\hline & \multicolumn{2}{|c|}{ Treatment $^{1}$} & \multirow[b]{2}{*}{ SEM } & \multirow[b]{2}{*}{ F-Test } \\
\hline & $+\mathrm{EO}$ & $-\mathrm{EO}$ & & \\
\hline Pens, $\mathrm{n}$ & 23 & 23 & - & - \\
\hline Days of feed & 200 & 200 & - & - \\
\hline \multicolumn{5}{|l|}{ Feedlot Performance ${ }^{2}$} \\
\hline Initial BW, lb & 652 & 652 & 0.27 & 0.49 \\
\hline Final BW, lb & 1309 & 1311 & 4.60 & 0.74 \\
\hline $\mathrm{DMI}, \mathrm{lb} / \mathrm{d}$ & 22.7 & 22.7 & 0.12 & 0.94 \\
\hline $\mathrm{ADG}, \mathrm{lb} / \mathrm{d}$ & 3.31 & 3.32 & 0.02 & 0.76 \\
\hline $\mathrm{F}: \mathrm{G}$ & 6.87 & 6.87 & - & 0.66 \\
\hline NEm Mcal/lb & 0.803 & 0.798 & 0.003 & 0.29 \\
\hline NEg Mcal/lb & 0.522 & 0.517 & 0.003 & 0.33 \\
\hline Return, $\$ / \mathrm{h}$ & 12.86 & 12.69 & 5.06 & 0.98 \\
\hline \multicolumn{5}{|l|}{ Carcass Characteristics } \\
\hline $\mathrm{HCW}, \mathrm{lb}$ & 835 & 836 & 3.00 & 0.72 \\
\hline LM area, in ${ }^{2}$ & 12.8 & 13.1 & 0.08 & 0.04 \\
\hline 12th rib fat, in & 0.506 & 0.506 & 0.009 & 0.99 \\
\hline Marbling $^{3}$ & 453 & 466 & 5.90 & 0.13 \\
\hline Calculated Yield Grade ${ }^{4}$ & 3.18 & 3.20 & 0.024 & 0.61 \\
\hline \multicolumn{5}{|l|}{${ }^{1}$ EO: essential oils } \\
\hline Calculated on a carcass-adjuste & common $\mathrm{d}$ & rcentage (63 & & \\
\hline Marbling Score 300 = Slight, 40 & $=$ Modest, & & & \\
\hline
\end{tabular}

Table 3. Main effect of corn silage on carcass adjusted performance of cattle fed three inclusions of corn silage.

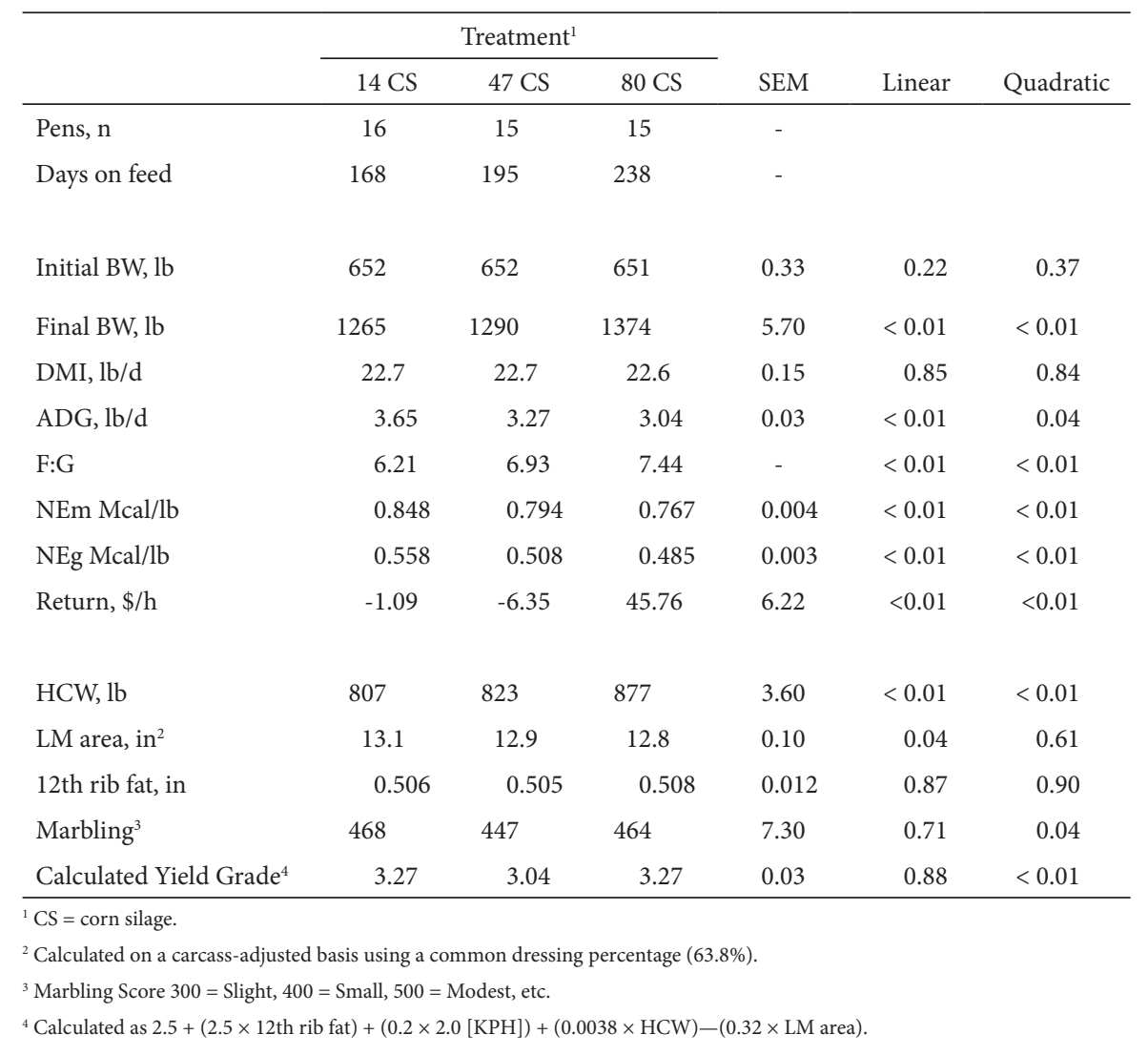


Table 4. Estimated returns ( $\mathbf{~ / ~ h d ) ~ a t ~ v a r y i n g ~ c o r n ~ p r i c e s ~ f o r ~ t h r e e ~ i n c l u s i o n s ~ o f ~ c o r n ~ s i l a g e ~ f e d ~ t o ~}$ feedlot cattle. ${ }^{1}$

\begin{tabular}{lcccc}
\hline & \multicolumn{3}{c}{ Treatment $^{2}$} & \\
\cline { 2 - 4 } Dry Corn Price ${ }^{3}, \$ /$ bu & Feeder Calf Price $^{4}$, / cwt & 14 CS & 47 CS & 80 CS \\
\hline 3.00 & 1.9313 & 0.03 & -5.86 & 42.02 \\
4.00 & 1.8243 & 0.01 & 2.07 & 50.86 \\
5.00 & 1.7172 & 0.06 & 1.77 & 59.76 \\
\hline
\end{tabular}

${ }^{1}$ Returns calculated as the difference in gross inputs and revenues. Values represent profit in dollars per head ( $\left.\$ / \mathrm{hd}\right)$.

Inputs: Total feed costs including processing and shrink. Cattle Interest $=[($ days on feed $/ 365) \times($ feeder price $-\$ 200) \times 0.75]$. Feed Interest $=[$ Total feed costs $/ 2) \times 0.75 \times($ days on feed $/ 365)]$. Yardage $=\$ 0.50 / \mathrm{hd} / \mathrm{d}$. Processing $=\$ 20 / \mathrm{hd}$.

Revenue: Final body weights using a $63 \%$ common dressing percent to calculate live final weight and 5 -year average live fat price for Nebraska ( $\$ 1.3055$ / cwt).

${ }^{2} \mathrm{CS}=$ corn silage.

${ }^{3}$ Corn silage prices floated with the price of corn utilizing a September corn price comparison ( $\$-0.20$ / bu) compared to $\$ 3$, $\$ 4$, and $\$ 5$ dry corn. The corn silage prices were $\$ 37.18$ (per ton DM), $\$ 45.00, \$ 52.82$, respectively.

${ }^{4}$ Initial purchase price was set to break even for $14 \%$ corn silage.

steer prices was conducted. The inclusion of EO did not impact returns $(P=0.98)$. Greater returns were projected as corn silage inclusion increased $(P<0.01)$ but the extent of returns was dependent on the price relationships for feed and steer prices. Projected profitability was least ( $\$ 6.35 /$ hd) for feeding $47 \%$ corn silage but the cattle did not gain as much HCW as past observed years at similar inclusions (2015 Nebraska Beef Cattle Report, pp. 66-67; 2018 Nebraska Beef Cattle Report, pp. 8991; 2019 Nebraska Beef Cattle Report, pp. 69-71) . Likely, this was due to longer days on feed relative to the to the cattle's ADG and fat deposition and not enough HCW. The greatest profitability ( $\$ 46.72 / \mathrm{hd}$ ) was projected from cattle fed $80 \%$ corn silage throughout the feeding period.

Because feed costs heavily influence profitability, differences in returns ( $\$$ / hd), based on corn price, were evaluated at the varying inclusions of corn silage (Table 4). As corn price (and corn silage price) increased there was a greater difference in the returns ( $\$ /$ hd) when cattle were fed $80 \%$ corn silage. For example, at $\$ 3.00$ corn, cattle fed $80 \%$ corn silage returned an additional \$42.02 per head compared to cattle fed $14 \%$ corn silage. Furthermore, when corn was $\$ 5.00$, returns were even greater ( $\$ 59.76 /$ hd) for cattle fed $80 \%$ corn silage compared to $14 \%$ corn silage. Cattle fed
$47 \%$ corn silage did not perform as expected. However, returns became greater than feeding at $14 \%$ when corn was $\$ 4$ or above. The same trend held true where increasing corn price led to an increase in returns as \$ / hd. These data suggest, as corn becomes more expensive, it becomes more economical to feed corn silage at greater inclusions.

\section{Conclusion}

In this study, inclusion of palm oil and fumaric acid (essential oils) did not affect animal performance. The inclusion of EO had no effects on performance, carcass quality or profitability. Greater inclusions of corn silage decreased ADG and F:G but led to greater final body weights when finished to a common back fat thickness. Additionally, $80 \%$ inclusion of silage led to increased profitability in dollars per head sold. Feeding corn silage with or without the inclusion of essential oils is economical.

Hannah C. Wilson, research technician

Bradley M. Boyd, research technician

F. Henry Hilscher, research technician

Zachary E. Carlson, research technician

Andrea K. Watson, associate professor

Jim C. MacDonald, associate professor

Galen E. Erickson, professor; University of Nebraska, Animal Science, Lincoln. 